\title{
SINTESE BIBLIOGRAFICA
}

\section{ATUALIDADES TERAPEUTICAS}

A powerfull depressant of gastric secretion ( $U m$ poderoso depressor da secreção gástrica) - Edit. do Am. Journ. Dig. Dis. vol. 6, n. 7, (Setembro) 1939, D. 473.

Farrel e Ivy (1926) mostraram que a secreçãa e a motilidade de uma bolsa gastrica enervada, transplantada, pode ser inibida pela ingestīo da gorduras. Evidentemente ha alguma substancia na gordura, que passa nara sangue e exerce efeito de tipo hormonal. Lim, na China, achou que "incsmo ef $\epsilon$ ito pode ser produzido por um estrato da mucosa duodenal. Recertemente Ivy e coil. mostraram que esta substancia - chamada agora enteroyastimic - consiste na verdade de 2 substancias, uma inibindo a secreção, c Jutra, inibindo a motilidade. Seguindo ros trabalhos de Sandweiss e coll. mostrando que os estratos de urina gravidica impedem as ulceras jejunais em aniniais submetidos á operação de Mann-Williamson, Ivy e coll, administraram este estrato a cães com bolsa de Pavlcv, e mostraram que havia uma sigmficante redução da secreção gastrica. Depois, Sandweiss achou que estratos de urina de mulher normal tambem sāo gastro-inibidores.

Os ultimos trabaihos de Gray, Wieczcrowski e Ivy (1937) mostraram quc estratos de urina de machos normais, são altamente inibıdores da secreção gastrica. Tres (3) millgrs. de material solido, obtido de $150 \mathrm{cc}$. de urina, conténı "1 unidade de enterogastrone", que, quando injetado num cão, reduz a secreção á metade. Este material é 60 vezes mais potente que o preparado de mucosa duodenal, e é mais livre de substancıas indesejaveis de máus ef alos; colaterais. Esta substancia não afeta a motilidade gastrica, mas apenas a secreção. Não se sabe ainda. si o "principio urinario" é igual ao "principio duodenal" E' de se esperar, que quando este produto fór aplicado á ierapeutica, muitas afeç̧ōes gastricas e duodenais, sobretudo a uicera peptica, encontrem tratamento mais fisiologico e etiologico.

$$
\text { E. IIATTAR }
$$

\section{TRATAMENTO DA PNEUMONIA COM SULFAPIRIDINA}

The treatment of pneumonia with sulfapyridine (Tratamento da pneumonia pela sulfapiridina) - Charles Hendee Smith - Resumo de 4 artigos publicados no "The Journal of Pediatrics", Vol. 15, N. ${ }^{\circ} 23$, September, 1939, seção - American Academy of Pediatrics, págs. 448 a 450.

A sulfapiridina mudou o inteiro aspecto da pneumonia na infancia, encurtando o tempo da molestia e diminuindo a incıdencia de complicaçōes nas crianças maiores, quando a mortalidade é baixa, e é ainda de ação nos latentes, onde' a pneumonia apresenta alta mortalidade.

$E^{\prime}$ importante verificar qual a varicdade de pneumococo presente. Existe provavelmente diferença etiologica entre pneumonia lobar (pneumococo) e broncho-pneumonia, que provavelmente é devida a um virus, sendo os germes encontrados meros invasores secundarios. $O A$. acha que na bronco-pneumo- 